- ORAL PRESENTATIONS -

\title{
FERTILIZING POTENTIAL OF WASTES FROM WINE AND ETHYL ALCOHOL PRODUCTION INDUSTRY
}

\author{
Vasile Plămădeală, Andrei Siuris, Alexandru Rusu, Ludmila Bulat \\ Institute of Pedology, Agro-chemistry and Soil Protection „NicolaeDimo”(IPAPS) \\ MD 2070, Chisinau, Republic of Moldova,
}

\begin{abstract}
In the processing of grapes and the production of alcoholic beverages, a total of about 100,000 cubic meters of wine lees, vinasse, grain mash and molasses are annually formed and accumulated in the Republic of Moldova. These wastes are characterized by a highly acidic chemical reaction and a high content of water-soluble salts. The $\mathrm{pH}$ ranges from 3.4 to 3.8 units. The mineral residue constitutes: $1.9 \mathrm{~g} / \mathrm{dm}^{3}$ in vinasse; $12.0 \mathrm{~g} / \mathrm{dm}^{3}$ in wine lees; and 14.9 $\mathrm{g} / \mathrm{dm}^{3}$ in grain mash. In the composition of monovalent cations, sodium and potassium cations predominate, which may form toxic salts if they penetrate into the soil. The cereal mashes are characterized by a higher potential of salinity and sodium enrichment. Also, these wastes contain primary nutritive elements (NPK) absolutely necessary for plant nutrition and soil fertilization. The total content of NPK in $\mathrm{kg} / \mathrm{m}^{3}$ in these wastes constitutes: 1.8 in vinasse; 5.1 in grain mash; 10.6 in wine lees. The dehydrated wine lees and grain mash have a high content of organic matter, $34 \%$ and $51 \%$ respectively. Due to their chemical composition and the highly acidic environment, they have a toxic impact on flora and fauna and a polluting action on surface and ground waters.

The administration of two doses of lees (13 and $26 \mathrm{t} / \mathrm{ha}$ ), of vinasse (300 and $600 \mathrm{~m}^{3} / \mathrm{ha}$ ) and of grain mash (50 and $100 \mathrm{~m}^{3} / \mathrm{ha}$ ) favoured the significant increase of the content of organic matter, mobile phosphorus, and exchangeable potassium in the arable soil layer. The application of wine lees in the dosage of $13-26$ t/ha ensured a significant increase of grapes by $1.4-2.4$ t/ha, or by $15-25 \%$ more than on the unfertilized control variant, on which 9.5 $\mathrm{t} /$ ha were harvested. The vinasse incorporated in a dosage of 300 and 600 $\mathrm{m}^{3} /$ ha had a significant impact on the plant productivity as well. The grape harvest constituted an average of $1.0-1.1 \mathrm{t} /$ ha or by $11-12 \%$ more than on the unfertilized control variant.
\end{abstract}

Keywords: wine yeast, vinasse, grain mash, soil, humus, mobile phosphorus, waste. 


\section{INTRODUCTION}

Currently the wineries and divisions of cognac and alcohol production at republican level accumulate about 20-25 thousand tons of wine lees, not less than 50 thousand cubic meters of vinasse and 45-50 thousand of cubic meters of grain mash and molasses as wastes (Statistical Year Book of the Republic of Moldova, 2014). The total volume of wastes in the wine industry is impressive and in continuous growth. The mineral residue of such wastes makes up to $2.0-$ $2.7 \mathrm{~g} / \mathrm{dm}^{3}$ which characterizes them as liquids with high mineralization. The SAR indicator is 6.0 higher, while the Stebler coefficient is $9-16$, the norm being 18 and more. The grain mashes have a higher salinity potential, their Stebler coefficient being of 6-7. The greatest danger of saline and alkaline contamination of the soils can be caused by their abusive incorporation and uncontrolled discharge.

The given wastes also contain primary elements necessary for agricultural plant nutrition and soil fertilization, which need insistent recovery. About $210 \mathrm{~kg}$ of nitrogen, $100 \mathrm{~kg}$ of phosphorus and $750 \mathrm{~kg}$ of total potassium are contained in 100 $\mathrm{m}^{3}$ of wine lees. The grain mashes and the vinasse are less concentrated in nutritive elements, but they are not to be overlooked. These wastes are not used in any way; moreover there are no regulations on their disposal. The mentioned wastes originate from agriculture, so all the elements contained in them are taken from the soil. It would be fair if the soil could recover them through fertilization. The amount of wastes subjected to the study was of about 100,000 tons per year, which contain about 28 thousand of organic matter, 180 tons of total nitrogen, 82 tons of total phosphorus and 257 tons of total potassium.

Being continuously accumulated and discharged without any norms, such wastes cause a polluting impact on the environment, especially on the soil and ground waters $[2,3]$. There is little research done on their properties and application in agriculture $[4,5,7,8,11]$ at international level and it is entirely absent in the Republic of Moldova. In this context, it is imperative to solve the issue of the mentioned wastes by applying them in agriculture as fertilizers.

The aim of the present paper is to study the chemical composition of such wastes in order to assess their potential as soil fertilizers and their impact on crop productivity.

\section{EXPERIMENTAL PART}

The research was conducted in the period $2010-2014$ on samples of wastes originating from grape processing industry and cognac and ethylic alcohol production from cereals. Wine lees, vinasse, cereal mashes and soil served as object of study. The investigations and observations on the assessment of the fertilizing potential of wine lees, vinasse and cereal mashes were carried out at the Experimental Station "Codru " from Chisinau. The experience is located on silt-clay levigated chernozem which contains: humus - 
$4.31 \%$; accessible $\mathrm{P}_{2} \mathrm{O}_{5}-34.2$ ppm; accessible $\mathrm{K}_{2} \mathrm{O}-430$ ppm ; pH 6.8. The wastes were applied on a grape-bearing vineyard of the sort Sauvignon. The scheme of the experience includes the following variants: 1 - unfertilized control; 2. -fertilized with wine lees, $13 \mathrm{t} /$ ha (equivalent to $\mathrm{N}_{100}$ ); 3 . - fertilized with wine lees, 26 tha (equivalent to $\mathrm{N}_{200}$ ); 4. -fertilized withvinasse 300 (equivalent to $\mathrm{K}_{450}$ ); 5 - fertilized with vinasse 600 (equivalent to $\mathrm{K}_{900}$ ). The research area of the plot was of $55 \mathrm{~m}^{2}$; the number of repetitions -3 . The testing of the grain mashes was also performed on silt-clay levigated chernozem according to the following scheme: 1 - unfertilized control; 2 fertilized with grain mashes, $50 \mathrm{~m}^{3} / \mathrm{ha}$ (equivalent to $\mathrm{N}_{120}$ ); 3 . - fertilized with grain mashes $100 \mathrm{~m}^{3} / \mathrm{ha}$ (equivalent to $\mathrm{N}_{240}$ ), the research area of the plot is of $120 \mathrm{~m}^{2}$; the number of repetitions -4 .

The following methods were used in the analysis of the wastes: humidity - STAS 26713-85, organic matter - STAS 27980-88, pH - STAS 27979-88; ashes - STAS 2671 -85, total nitrogen - STAS 26715-75, total phosphorus STAS 26717- 85, total potassium - STAS 26718 - 85, N-NO $\mathrm{NO}_{3}$-after Grandval Leaju, $\mathrm{N}-\mathrm{NH}_{4}$ - STAS 26716-85, aqueous extract STAS 26428- 85.

The methods used in soil analysis are the following: - humus - after Tiurin

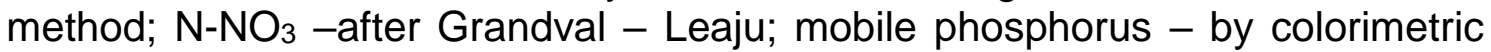
dosage determination after Macighin; exchangeable potassium after Macighin through photo-metering flame; $\mathrm{pH}$ - potentiometric method; aqueous extract STAS 26428-85. The statistical processing of the results obtained within the investigation was performed according to B. Dospehov [9].

\section{REZULTS AND DISCUSSION}

Wine lees is a waste of the wine industry, which is formed as result of grape juice fermentation with yeast. As a rule, about $10-15 \%$ of wine lees is formed from the amount subjected to fermentation, which is in a semi-solid state with a content of solid matter of $12-13 \%$.

Currently, depending on the existing equipment, the wineries extract ethylic alcohol from wine lees through distillation. In addition, they can be dehydrated by press-filters. With or without dehydration the lees is discarded into the environment. The carried out research (Gh., Duca, 2011;O. Chiselița, 2010) regarding the possibility to use them as nutritive additions in animal fodder is very interesting. The solid lees is characterized by a content of $48 \%$ humidity, $46.8 \%$ organic matter and $5.3 \%$ of ashes. Potassium, nitrogen and phosphorus predominate among the biophile elements. The content is of 2.6; 1.5 and $07 \%$ respectively in the natural humidity mass (Table 1). One ton of such yeasts contains $48 \mathrm{~kg}$ of NPK, with a ratio of 1:0,5:1,7 of these elements, which approximately corresponds to the nutritive needs of the main crops. The proportion of carbon:nitrogen constitutes $16: 1$, being similar by nitrogen release ability to that of the manure $17: 1$. 
Table 1

\section{Chemical composition of solid wine yeasts from wineries, related to the natural humidity mass}

\begin{tabular}{|l|c|c|c|c|c|c|c|c|}
\hline $\begin{array}{c}\text { Component and } \\
\text { measure unit }\end{array}$ & $\mathrm{x}$ & $\min$ & $\max$ & $\mathrm{S}$ & $\mathrm{V} \%$ & $\mathrm{Sx}$ & $\mathrm{Sx} \%$ & $\begin{array}{c}\Delta \mathrm{x} \\
( \pm)\end{array}$ \\
\hline $\mathrm{pH}$ & 3.5 & 3.20 & 3.7 & 0.12 & 3.5 & 0.07 & 2.0 & 0,2 \\
\hline Humidity, \% & 48.0 & 42.0 & 58.9 & 9.6 & 20.0 & 5.5 & 11.6 & 18 \\
\hline Organic matter,\% & 46.8 & 38.3 & 50.3 & 9.5 & 20.3 & 5.5 & 11.7 & 17,6 \\
\hline Ash, \% & 5.3 & 2.8 & 8.8 & 3.1 & 55.0 & 1.7 & 32.0 & 5.1 \\
\hline Carbon, \% C & 23.4 & 19.2 & 25.5 & 1.2 & 5.2 & 0.6 & 2.6 & 2.0 \\
\hline Total nitrogen, \% $\mathrm{N}$ & 1.5 & 0.77 & 1.81 & 0.6 & 40.0 & 0.35 & 23.0 & 1.1 \\
\hline $\mathrm{N}-\mathrm{NO}_{3}, \mathrm{ppm}$ & 16 & 7,1 & 26 & 0.68 & 42.5 & 0.30 & 0.002 & 9,9 \\
\hline $\mathrm{N}^{\mathrm{N} \mathrm{N}_{4}, \mathrm{ppm}}$ & 329 & 269 & 517 & 2.41 & 7.32 & 1.08 & 3.28 & 35,5 \\
\hline Total phosphorus, \% $\mathrm{P}_{2} \mathrm{O}_{5}$ & 0.70 & 0.60 & 0.79 & 0.12 & 18.5 & 0.07 & 10.6 & 0.2 \\
\hline Total potassium, \% $\mathrm{K}_{2} \mathrm{O}$ & 2.6 & 2.3 & 2.7 & 0.26 & 10.2 & 0.15 & 5.8 & 0.5 \\
\hline
\end{tabular}

Note: $x$ - average arithmetic value; min - the minimum encountered value; max -maximum encountered value; $S$-standard deviation of the average; v - variation coefficient; $S x$ precision of average in absolute quantity; Sx\% - relative precision of average; $\Delta \mathrm{x}$ - interval of average likelihood at $95 \%$ probability.

The liquid wine lees is characterized by a high content of water, about 95,0 $\%$. The content of organic matter and minerals is of $3.4 \%$ and $1.2 \%$ respectively. Total potassium, nitrogen and phosphorus prevail among biophile elements (Table 2). The contents of total potassium constitutes an average of $0.75 \%$, total nitrogen $-0,21 \%$ and total phosphorus - $0.1 \%$. Among the cations, monovalent potassium and sodium prevail. Their concentration constitutes 4.2 and $0.47 \mathrm{~g} / \mathrm{dm} 3$ respectively. Among the bivalent cations, calcium $-240 \mathrm{mg} / \mathrm{dm}^{3}$ and magnesium $92 \mathrm{mg} / \mathrm{dm}^{3}$ prevail. Sulphates prevail in the composition of anions. Their concentration makes up on average 0.34 $\mathrm{g} / \mathrm{dm}^{3}$, and $0.13 \mathrm{~g} / \mathrm{dm}^{3}$ of the chlorine. In the mineral form of nitrogen, $\mathrm{N}-\mathrm{NH}_{4}$ $121 \mathrm{mg} / \mathrm{dm}^{3}$ prevails and $\mathrm{N}-\mathrm{NO}_{3}$ constitutes $13 \mathrm{mg} / \mathrm{dm}^{3}$. A cubic meter of lees contains $10.3 \mathrm{~kg}$ of NPK. They can be used as a source of nutritive elements.

Table 2

\section{Chemical composition of waste from grape processing and alcohol production}

\begin{tabular}{|l|c|c|c|}
\hline \multicolumn{1}{|c|}{$\begin{array}{c}\text { Component and unit of } \\
\text { measure }\end{array}$} & Wine lees & Vinasse & Grain mash \\
\hline $\mathrm{pH}$ & $3.8 \pm 0.7$ & $3.4 \pm 0.4$ & $3.7 \pm 0.3$ \\
\hline Total residue, $\mathrm{g} / \mathrm{dm}^{3}$ & $46.0 \pm 29$ & $15.2 \pm 9.2$ & $66.3 \pm 4.8$ \\
\hline Mineral residue, $\mathrm{g} / \mathrm{dm}^{3}$ & $12.0 \pm 8$ & $1.9 \pm 1.3$ & $14.9 \pm 1.4$ \\
\hline organic matter, \% & $34.0 \pm 28$ & $1.3 \pm 1.2$ & $51.4 \pm 5.5$ \\
\hline Total nitrogen, \% $\mathrm{N}$ & $0.21 \pm 0.2$ & $0.02 \pm 0.01$ & $0.28 \pm 0.04$ \\
\hline $\mathrm{N}-\mathrm{NO}_{3}, \mathrm{mg} / \mathrm{dm}^{3}$ & $13 \pm 8$ & $9.3 \pm 9.0$ & $5.8 \pm 3.6$ \\
\hline $\mathrm{N}-\mathrm{NH}_{4}, \mathrm{mg} / \mathrm{dm}^{3}$ & $121 \pm 59$ & $67.4 \pm 35.6$ & $143 \pm 62$ \\
\hline
\end{tabular}




\begin{tabular}{|l|c|c|c|}
\hline Total phosphorus, \% $\mathrm{P}_{2} \mathrm{O}_{5}$ & $0.1 \pm 0.07$ & $0.02 \pm 0.01$ & $0.12 \pm 0.07$ \\
\hline Total potassium, \% $\mathrm{K}_{2} \mathrm{O}$ & $0.75 \pm 0.60$ & $0.12 \pm 0.05$ & $0.11 \pm 0.02$ \\
\hline Humidity, \% & $95.2 \pm 2.3$ & $98.5 \pm 1.01$ & $93.4 \pm 1.6$ \\
\hline $\mathrm{Ca}^{+2,} \mathrm{mg} / \mathrm{dm}^{3}$ & $240 \pm 99$ & $106 \pm 23$ & $97 \pm 27$ \\
\hline $\mathrm{Mg}^{+2}, \mathrm{mg} / \mathrm{dm}^{3}$ & $92 \pm 52$ & $84 \pm 42$ & $234 \pm 86$ \\
\hline $\mathrm{Na}^{+}, \mathrm{mg} / \mathrm{dm}^{3}$ & $471 \pm 158$ & $172 \pm 51$ & $450 \pm 194$ \\
\hline $\mathrm{K}^{+}, \mathrm{mg} / \mathrm{dm}^{3}$ & $4188 \pm 2085$ & $579 \pm 418$ & $783 \pm 166$ \\
\hline $\mathrm{Cl}^{-}, \mathrm{mg} / \mathrm{dm}^{3}$ & $131 \pm 28$ & $90 \pm 28$ & $299 \pm 98$ \\
\hline $\mathrm{SO}_{4}^{-2}, \mathrm{mg} / \mathrm{dm}^{3}$ & $340 \pm 117$ & $155 \pm 88$ & $357 \pm 140$ \\
\hline
\end{tabular}

Vinasse is formed as waste as a result of wine distillation in order to get wine distillate. However, the processing of secondary products derived from wine distillation in order to obtain alcohol for cognac and rectified alcohol, as well as the wastes resulting from obtaining alcohol from molasses, doesn't currently have solutions for use. The vinasse derived from secondary wine products distillation is primarily used for obtaining tartaric acid compounds. Not being used for other purposes (such as obtaining food for animals), it is basically discharged into the sewer system preventing the development of aerobic biological processes, currently used in wastewater treatment plants, and also significantly damaging the environment $[3,10]$.

We studied the composition and properties of this waste in terms of its influence on the agrochemical and agro-ameliorative soil properties. We have determined the indicators that directly contribute to the soil quality modification to use vinasse, if possible, as a fertilizing source for the soil and to diminish the negative impact on the quality of natural waters, as result of its direct discharges into surface waters.

From this point of view, vinasse is characterized by an acid environment, $\mathrm{pH}$ ranges from 3.0 to 3.8 with an average value of 3.4 units. Dry residue varies from 6.0 to $24.4 \mathrm{~g} / \mathrm{dm}^{3}$, forming an average of $15.2 \mathrm{~g} / \mathrm{dm}^{3}$. The content of organic matter constitutes on average $13.3 \mathrm{~g} / \mathrm{dm}^{3}$, with a variation between 0.6 to $26 \mathrm{~g} / \mathrm{dm}^{3}$. Mineral compounds content ranges from 0.6 to $3.2 \mathrm{~g} / \mathrm{dm}^{3}$ with an average of $1.9 \mathrm{~g} / \mathrm{dm}^{3}$. The potassium content, with an average value of $0.12 \%$, prevails in vinasse composition among the biophile elements. The content of total nitrogen and phosphorus makes up an average of $0.02 \%$. Ammoniacal nitrogen constitutes about $34 \%$ of the total nitrogen content (Table 2). Monovalent cations prevail in vinasse; potassium - 579 and sodium - 172 $\mathrm{mg} / \mathrm{dm}^{3}$. The concentration of the bivalent cations, calcium and magnesium is of 106 and $84 \mathrm{mg} / \mathrm{dm}^{3}$ on average, with a corresponding variation from 83-42 to $129-126 \mathrm{mg} / \mathrm{dm}^{3}$. Sulphates content prevails among anions. Their concentration is of $155 \mathrm{mg} / \mathrm{dm}^{3}$ on average. Chlorine content ranges from 62 to $118 \mathrm{mg} / \mathrm{dm}^{3}$ forming $90 \mathrm{mg} / \mathrm{dm}^{3}$ on average.

In recent years, the industry for producing ethylic alcohol from cereals (wheat, barley, corn) is actively developing. According to the calculations based on data contained in the Statistical Yearbook of the Republic of Moldova, 2014, in recent years, about 50 thousand cubic meters of grain mash are annually formed in the Republic of Moldova. The specialized literature indicates that almost a third of the dry corn raw material gets into the mash. The content of dry matter in the mash varies between 4 and $8 \%$, and it is predominantly formed of protein substances, hemicellulose, cellulose, starch, pentose, etc. [6]. 
We have studied the composition and properties of the grain mash, in terms of its influence on soil ameliorative properties, in order to exploit it as a source of soil fertilization and to decrease its negative impact on the environment.

The grain mash is characterized by containing $93.4 \%$ of water and 6.63 $\%$ of dry matter. The content of organic matter varies from 45.9 to $56.9 \mathrm{~g} / \mathrm{dm}^{3}$ with an average value of $51.4 \mathrm{~g} / \mathrm{dm}^{3}$. The mineral residue makes up to 14.9 $\mathrm{g} / \mathrm{dm}^{3}$ with a value of $8.7 \%$. Among the biophile elements, nitrogen content prevails $-0.28 \%$, phosphorus $-0.12 \%$ and potassium $-0.11 \%$ (Table 2 ).

Having analysed the aqueous extract we concluded that the grain mash has an acid reaction with an average value of $\mathrm{pH}$ of 3.7 units and varies from 3.4 to 4 units. Among the cations, monovalent potassium and sodium cations prevail -783 and $450 \mathrm{mg} / \mathrm{dm}^{3}$ correspondingly. The concentration of calcium and magnesium cations is of 97 and $234 \mathrm{mg} / \mathrm{dm}^{3}$ in average respectively. Sulphates prevails among anions. Their content is on average of $357 \mathrm{mg} / \mathrm{dm}^{3}$. Chlorine ions concentration varies from 202 to $397 \mathrm{mg} / \mathrm{dm}^{3}$ with an average value of $299 \mathrm{mg} / \mathrm{ldm}^{3}$. Grain mash can be used as a fertilizing source considering its biofile elements and the organic matter it contains.

The average data, obtained in a four-year period, demonstrated that the administration of lees in a dosage of 13 and $26 \mathrm{t} / \mathrm{ha}$, leads to a significant increase of the content of organic matter and exchangeable phosphorus in the $0-30 \mathrm{~cm}$ soil layer. The increase of the organic matter in the arable layer constituted $0.23 \%$ and $0.39 \%$ or 6168 and $10374 \mathrm{~kg} / \mathrm{ha}$ respectively. The average value of accessible phosphorus, compared to the control variant, grew by $4.7 \mathrm{ppm}$ or $10.6-14.5 \mathrm{~kg} / \mathrm{ha}$. Incorporation of vinasse in the dosage of 300 $\left(\mathrm{K}_{450}\right)$ and $600 \mathrm{~m}^{3} / \mathrm{ha}\left(\mathrm{K}_{900}\right)$ also leads to a significant increase of the content of organic matter, mobile phosphorus and exchangeable potassium. The increase of the organic matter compared to the control variant in the $0-30 \mathrm{~cm}$ soil layer constituted 0.22 and $0.34 \%$ or 5852 and $9044 \mathrm{~kg} / \mathrm{ha}$, of the mobile phosphorus - $2.0-3.6 \mathrm{ppm}$ or $4.5-8.1 \mathrm{~kg} / \mathrm{ha}$ (Table 3 ).

Table 3

Impact of wine waste on the content of nutritive substances in the $\mathbf{0 - 3 0} \mathrm{cm}$ layer of levigated chernozem (Technological-experimental Station "Codru")

\begin{tabular}{|c|c|c|c|c|c|c|c|c|c|}
\hline \multirow{3}{*}{ Variant } & \multicolumn{3}{|c|}{ organic matter ,\% } & \multicolumn{3}{|c|}{$\mathrm{P}_{2} \mathrm{O}_{5}, \mathrm{ppm}$} & \multicolumn{3}{|c|}{$\mathrm{K}_{2} \mathrm{O}, \mathrm{ppm}$} \\
\hline & \multirow[t]{2}{*}{$\begin{array}{c}\text { average } \\
2011- \\
2014\end{array}$} & \multicolumn{2}{|c|}{$\begin{array}{c}\text { Increase } \\
\text { compared to } \\
\text { control variant }\end{array}$} & \multirow[t]{2}{*}{$\begin{array}{c}\text { average } \\
2011- \\
2014\end{array}$} & \multicolumn{2}{|c|}{$\begin{array}{l}\text { Increase } \\
\text { compared to } \\
\text { control } \\
\text { variant }\end{array}$} & \multirow[t]{2}{*}{$\begin{array}{l}\text { average } \\
2011- \\
2014\end{array}$} & \multicolumn{2}{|c|}{$\begin{array}{c}\text { Increase } \\
\text { compared } \\
\text { to control } \\
\text { variant }\end{array}$} \\
\hline & & $\%$ & $\mathrm{~kg} / \mathrm{ha}$ & & ppm & $\begin{array}{l}\mathrm{kg} / \mathrm{h} \\
\mathrm{a}\end{array}$ & & ppm & $\begin{array}{l}\mathrm{kg} / \mathrm{h} \\
\mathrm{a}\end{array}$ \\
\hline Control & 4.05 & - & - & 22,5 & - & - & 290 & - & - \\
\hline $\begin{array}{l}\text { Wine lees, } \\
13 \mathrm{t} / \mathrm{ha}\end{array}$ & 4.28 & 0.23 & 6118 & 27.2 & 4.7 & 10.6 & 360 & 70 & 160 \\
\hline $\begin{array}{l}\text { Wine lees, } \\
26 \mathrm{t} / \mathrm{ha}\end{array}$ & 4.44 & 0.39 & 10374 & 28.9 & 6.4 & 14.5 & 380 & 90 & 206 \\
\hline $\begin{array}{l}\text { Vinasse, } \\
300 \mathrm{~m}^{3} / \mathrm{ha}\end{array}$ & 4.27 & 0.22 & 5852 & 24.5 & 2.0 & 4.5 & 400 & 110 & 251 \\
\hline $\begin{array}{l}\text { Vinasse, } \\
600 \mathrm{~m}^{3} / \mathrm{ha}\end{array}$ & 4.39 & 0.34 & 9044 & 26.1 & 3.6 & 8.1 & 440 & 150 & 342 \\
\hline DL 05,\% & 0.17 & 0.17 & 4522 & 1.5 & 1.5 & 3.4 & 67 & 67 & 153 \\
\hline $\mathrm{P}, \%$ & 5.1 & 5.1 & 5.1 & 8.9 & 8.9 & 8.9 & 9.1 & 9.1 & 9.1 \\
\hline
\end{tabular}


Fertilization with grain mash in the dosage of $50\left(\mathrm{~N}_{120}\right)$ and $100 \mathrm{~m}^{3} / \mathrm{ha}\left(\mathrm{N}_{240}\right)$ led to a significant increase of the content of organic matter and mobile phosphorus in the soil. The value of the organic matter increase on average for a period of three years constituted $0.15 \%$ and $0.25 \%$ or 3780 and $6300 \mathrm{~kg} / \mathrm{ha}$ and of mobile phosphorus -2.1 and $4.6 \mathrm{ppm}$ or 4.7 and $10.4 \mathrm{~kg} / \mathrm{ha}$. As for the accessible potassium content, a sure increase compared to the control variant was statistically recorded at the incorporation of vinasse in the dosage of 300 and $600 \mathrm{~m}^{3} / \mathrm{ha}$ and of grain mash in the dosage of $100 \mathrm{~m}^{3} / \mathrm{ha}$ (Table 4).

Impact of grain mash on the content of nutritive substances in the arable layer of levigated chernozem

\begin{tabular}{|c|c|c|c|c|c|c|c|c|c|}
\hline \multirow{3}{*}{ Variant } & \multicolumn{3}{|c|}{ organic matter $\%$} & \multicolumn{3}{|c|}{$\mathrm{P}_{2} \mathrm{O}_{5}, \mathrm{ppm}$} & \multicolumn{3}{|c|}{$\mathrm{K}_{2} \mathrm{O}, \mathrm{ppm}$} \\
\hline & \multirow[t]{2}{*}{$\begin{array}{c}\text { average } \\
2011- \\
2014\end{array}$} & \multicolumn{2}{|c|}{$\begin{array}{l}\text { Increase } \\
\text { compared } \\
\text { to control }\end{array}$} & \multirow[t]{2}{*}{$\begin{array}{c}\text { average } \\
2011- \\
2014\end{array}$} & \multicolumn{2}{|c|}{$\begin{array}{l}\text { Increase } \\
\text { compared } \\
\text { to control }\end{array}$} & \multirow[t]{2}{*}{$\begin{array}{c}\text { average } \\
2011- \\
2014\end{array}$} & \multicolumn{2}{|c|}{$\begin{array}{l}\text { Increase } \\
\text { compared } \\
\text { to control }\end{array}$} \\
\hline & & $\%$ & $\begin{array}{l}\mathrm{kg} / \mathrm{h} \\
\mathrm{a}\end{array}$ & & ppm & $\begin{array}{l}\mathrm{kg} / \mathrm{h} \\
\mathrm{a}\end{array}$ & & ppm & $\begin{array}{l}\mathrm{kg} / \mathrm{h} \\
\mathrm{a}\end{array}$ \\
\hline Control & 2.93 & - & - & 23.1 & - & - & 260 & - & - \\
\hline $\begin{array}{l}\text { Grain mash, } \\
50 \mathrm{~m}^{3} / \mathrm{ha}\end{array}$ & 3.08 & 0.15 & 3780 & 25.2 & 2.1 & 4.7 & 290 & 30 & 68 \\
\hline $\begin{array}{l}\text { Grain mash, } \\
100 \mathrm{~m}^{3} / \mathrm{ha}\end{array}$ & 3.18 & 0.25 & 6300 & 27.7 & 4.6 & 10.4 & 320 & 60 & 136 \\
\hline DL 05,\% & 0.12 & 0.12 & 2048 & 1.4 & 1.4 & 6.9 & 38 & 38 & 63 \\
\hline $\mathrm{P}, \%$ & 8.2 & 8.2 & 8.2 & 7.3 & 7.3 & 7.3 & 10.7 & 10.7 & 10.7 \\
\hline
\end{tabular}

The results of the research conducted over a period of four years with the application of wine wastes in the cultivation of grape-vine and field crops demonstrate that they have a beneficial impact on plant productivity (Table 5). Application of wine lees in the dosage of 13-26 t/ha annually, ensured a significant increase of grape harvest on average by $1.4-2.4 \mathrm{t} / \mathrm{ha}$, or by $15-25$ $\%$ more compared to the unfertilized control variant $(9.5 \mathrm{t} / \mathrm{ha})$.

Vinasse incorporated in a dosage of 300 and $600 \mathrm{~m}^{3} / \mathrm{ha}$ annually had a significant beneficial effect on the productivity of grapevines as well. The increase of harvest on average per year constituted $1.0-1.1 \mathrm{t} / \mathrm{ha}$ or $11-12 \%$ more compared to the unfertilized control variant.

Table 5

Impact of wine wastes on Sauvignon grape harvest obtained on cambic chernozem, $\mathbf{t} /$ ha

\begin{tabular}{|l|c|c|c|c|c|c|c|}
\hline \multirow{2}{*}{ Variant } & \multicolumn{4}{|c|}{$\begin{array}{c}\text { Grape harvest by year of } \\
\text { research }\end{array}$} & \multicolumn{3}{c|}{$\begin{array}{c}\text { Average for four } \\
\text { years }\end{array}$} \\
\cline { 2 - 9 } & 2011 & 201 & 201 & 201 & t/ha & \multicolumn{2}{c|}{$\begin{array}{c}\text { Harvest } \\
\text { increase }\end{array}$} \\
\cline { 2 - 9 } & & 2 & 3 & 4 & & $t$ & $\%$ \\
\hline Control & 9.8 & 7.6 & 10.6 & 9.8 & 9.5 & - & - \\
\hline Wine lees, $13 \mathrm{t} / \mathrm{ha}$ & 10.8 & 8.7 & 11.9 & 12.0 & 10.9 & 1.4 & 15 \\
\hline Wine lees, $26 \mathrm{t} / \mathrm{ha}$ & 10.9 & 8.8 & 14.1 & 13.9 & 11.9 & 2.4 & 25 \\
\hline Vinasse, $300 \mathrm{~m}^{3} / \mathrm{ha}$ & 10.8 & 8.7 & 12.0 & 10.5 & 10.5 & 1.0 & 11 \\
\hline Vinasse, $600 \mathrm{~m}^{3} / \mathrm{ha}$ & 10.6 & 8.5 & 12.6 & 10.6 & 10.6 & 1.1 & 12 \\
\hline $\mathrm{DL} 05 \%$ & 0.60 & 0.64 & 0.94 & 0.75 & - & 0.73 & - \\
\hline $\mathrm{P}, \%$ & 14.3 & 15.1 & 17.2 & 16.1 & - & 15.7 & - \\
\hline
\end{tabular}


Table 6

Impact on field crop harvest fertilized with grain mash, $\mathrm{kg} / \mathrm{ha}$

\begin{tabular}{|l|c|c|c|c|c|c|}
\hline \multirow{2}{*}{ Variant } & \multicolumn{3}{|c|}{ Main crop production } & \multicolumn{2}{c|}{$\begin{array}{c}\text { Average for three } \\
\text { years, cereal units }\end{array}$} \\
\cline { 2 - 7 } & $\begin{array}{c}2012, \\
\text { sunflower }\end{array}$ & $\begin{array}{c}2013, \\
\text { Winter } \\
\text { wheat }\end{array}$ & $\begin{array}{c}2014, \\
\text { sunflowe } \\
r\end{array}$ & $\mathrm{~kg} / \mathrm{ha}$ & \multicolumn{2}{|c|}{$\begin{array}{c}\text { Harvest } \\
\text { increase }\end{array}$} \\
\cline { 2 - 7 } & 1230 & 3818 & 1170 & 2449 & - & - \\
\hline Control & 1840 & 5673 & 1790 & 3670 & 1221 & 50 \\
\hline $\begin{array}{l}\text { Grain mash, 50 } \\
\mathrm{m}^{3} / \mathrm{ha}\end{array}$ & 2070 & 6183 & 1980 & 4046 & 1597 & 65 \\
\hline $\begin{array}{l}\text { Grain mash, 100 } \\
\mathrm{m}^{3} / \mathrm{ha}\end{array}$ & 223 & 520 & 172 & - & 305 & - \\
\hline $\mathrm{DL} \mathrm{05, \%}$ & 10.4 & 12.3 & 11.6 & - & 11.4 & - \\
\hline $\mathrm{P}, \%$ & & & & & & \\
\hline
\end{tabular}

The research has shown that fertilization with grain mash led to a significant increase of field crop productivity. Grain mash applied annually in a dosage of 50 and $100 \mathrm{~m}^{3} /$ ha (equivalent to $N_{120}$ and $N_{240}$ ) contributed to obtaining some average increases of production from 1221 to $1597 \mathrm{~kg} / \mathrm{ha}$ of cereal units or by $50-65 \%$ more compared to the unfertilized control variant.

\section{Conclusions}

The incorporation of wastes into the soil as fertilizers contributed to the improvement of levigated chernozem fertility and the growth of crop productivity. Fertilization with wastes from alcoholic beverages production led to a significant increase of the content of organic matter $(0.15-0.39 \%)$, of the mobile phosphorus (2.0-6.4 ppm) and of the exchangeable potassium (60-150 ppm).

Application of wine lees secured significant increase in the production of grapes (Sauvignon) by $1.4-2.4$ t/ha on average for a period of four years. The incorporation of vinasse led to an increase of harvest by $1.0-1.1 \mathrm{t} / \mathrm{ha}$ on average. The applied grain mash contributed to obtaining an average increase of vegetal production by 1200 - $1600 \mathrm{~kg} / \mathrm{ha}$ cereal units or by $50-65 \%$ compared to the unfertilized control variant. Annual incorporation for a period of four years of wine lees in the dosage of $13 \mathrm{t} / \mathrm{ha}$ and of vinasse in a dosage of $300 \mathrm{~m}^{3} /$ ha into grapevines formed a total harvest of $10.9-10.5 \mathrm{t} /$ ha ensuring a specific increase in grapes of $8.8 \mathrm{~kg} / \mathrm{m}^{3}$ from vinasse and $210 \mathrm{~kg} / \mathrm{t}$ from lees. The quality indicators of the crops have improved under the action of the applied wastes. 


\section{Bibliography}

1. Anuarul statistic al Republicii Moldova (Statistical Yearbook of the Republic of Moldova) . Chişinău: Statistica, 2014, p. 350-355.

2. Chiselița, O. Caracteristici fiziologo-biochimice ale unor drojdii vinicole și procedee de obținere a bioproduselor valoroase (Physiological and biochemical characteristics of some wine yeasts and processes for obtaining valuable bioproducts). Autoreferat al tezei de doctor în științe biologice (Abstract of PhD thesis in Biological Sciences) Chișinău, 2010,18 p.

3. Duca, G. Produse vinicole secundare (Secondary wine products). Chișinău: Știința, 2011, p.315-320.

4. Gemtos, T.A.; Chouliaras, N.; Marakis, Șt. Vinasse rate time of application and compation effect of soil proprieties and durum wheat crop. J.Agric. Engng. res (1999) 73, page 283-296.

5. Luz Ruggieai, Ersamo Cadena, Julia Martinez et. al. Recovery of organic waste in the Spanish wine industry. Technical, economic and environmental analyses of the composting process. Journal of cleaner production 17 (2009), page 830-838.

6. Niclic, V.; Petrușcă, C. Tehnologia ecologică integrată de fabricare a spirtului din cereale, cu valorificarea borhotului în biogaz și fertilizant.(Integrated ecological industry of producing spirit from grains by using the grain mash in biogas and as fertilizer), Simpozionul Internațional "Biocombustibilii în România" (International Symposium „Biofuels in Romania). București, 2006, p. 49-56.

7. Tejada, M.; Garcia-Martinez, A.M.; Parrado, J. Effects of a vermicompost composted with beet vinasse of soil properties, soil losses and soil restoration. Catena 77 (2009), page 238-247.

8. Гаина,Б. Экологияибиотехнологияпродуктовпереработкивинограда (Ecology and biotechnology of grape processing products). Кишинэу: Știința, 1990, p.7591.

9. Доспехов Б. Методика полевого опыта (Methods of field experience). Москва: Колос, 1990, с. 272-289.

10. Дука, Г. Основы процессов обезвреживания экологически вредных отходоввиноделия(Basics of neutralization processes of environmentally harmful wine wastes). Кишинэу, 2007, p. 215-218.

11. Корчагина, Н.А. Эффективность применения различных доз барды послеспиртовой на светло-серой лесной почве.(Effectiveness of applying different doses of vinasse from distillery on light grey forest soil) Нижегородскойаграрныйвестник. Нижний Новгород, 2012, с.212-216. 